\title{
Classification of Program Activities: How Nonprofits Create Social Value
}

\author{
William Brown \\ Bush School of Government and Public Service, Texas A \& M University, College Station, TX 77843, USA; \\ wbrown@tamu.edu \\ Academic Editor: Rita Mano \\ Received: 13 February 2017; Accepted: 10 May 2017; Published: 17 May 2017
}

\begin{abstract}
This paper defines and describes a framework to classify program activities utilized by nonprofit organizations to achieve public benefit objectives. Drawing on theory and practice from strategy, nonprofit management, and program planning, the paper proposes five program activities differentiated by the value created. Several factors define and differentiate the approaches and serve as decision areas for nonprofit managers when developing program strategies. Classifying program activities facilitates further research as it provides a common language and framework to analyze strategic choices enacted in nonprofit organizations.
\end{abstract}

Keywords: nonprofit strategy; program services

\section{Introduction}

Nonprofits engage in a variety of programs to produce public benefit outcomes. The United States Internal Revenue Service refers to these activities as "program services" and requires tax exempt organizations to detail "program service accomplishments" in part III of the form 990. The instructions define "a program service is an activity of an organization that accomplishes its exempt purpose". The proposed classification system emphases public benefit outcomes as the key distinction among activities. This paper defines and describes five program strategies that each result in different types of outcomes. This paper seeks to address a gap in both nonprofit management and the strategy literature that extends understanding on how managers enact programs to realize public benefit outcomes. Placing the paper in the context of strategic management provides an approach that is less common in nonprofit management literature [1-3] and extends program planning and evaluation literature. The nature and content of program activities are described in other areas $[4,5]$ but less so in relation to nonprofit strategy. Program strategy is comparable to 'business' strategy, which is defined as the tactics utilized to meet a distinct market opportunity [6]. In the nonprofits context, tactics are utilized to meet public benefit needs [7] which is analogous to 'market opportunity'. Business strategy literature explores, describes and analyses generic business approaches [8], but comparable literature is limited in the nonprofit context. The classification of program services supports further research that can compare utilization and performance of program strategies in nonprofit organizations. Classification supports analysis and understanding of nonprofit program activities $[9,10]$. The classification system facilitates research because it identifies variables that influence implementation and performance outcomes as well as providing an overall framework to understand how portfolios of program activities are utilized.

\section{Program Activities}

The classification of program activities is guided by framing intended outcomes across different levels of analysis (individual, community, and socio/political) and considering the focus of program activities. Outcomes are the benefits and change created as a result of program 
activities [11]. The classification of value creation systems [12,13] is distinct from efforts that classify organizations [14-18]. Nonprofit organizations may simultaneously address multiple types of outcomes [19], but the classification of program activities is based on the idea that there is unique actions related to each outcome of type. This draws on a perspective that conceptualizes program activities as the transformation mechanism to create outcomes [20]. The paper proposes classifying the approaches used by nonprofits organizations based on the value those program activities create. For classifications to be conceptually sound the categories should be mutually exclusive and conceptually exhaustive [21]. These program activities are conceptually distinct because they create different types of change. Consequently, each approach has a focus of activity that aligns with the intended outcome. The classification system is comprehensive as the outcome categories are drawn from the roles and functions of nonprofits $[15,17]$ and consequently encompass the range of functions nonprofits play in society. The paper seeks to elaborate the distinctions among different approaches by identifying features that have particular strategic and managerial implications.

Classifying program activities is important because explaining the range of program options and the challenges of those approaches facilities understanding of program choice options for managers [22]. This also facilitates research to compare and contrast program choices implemented in different contexts. Each program activity is based on a slightly different interpretation of social issues and requires unique competencies [23]. There is substantive variation within each program area, but that does not negate the distinctions between approaches. The five program areas are: service provider, community builder, advocacy actor, creator/innovator, preservation player (see Table 1).

Table 1. Classification of Program Activities.

\begin{tabular}{|c|c|c|c|c|c|}
\hline Level of Benefit & Individual & Community & Socio/Political & Innovation & Preservation \\
\hline Type of Activity & $\begin{array}{l}\text { Service } \\
\text { Provider }\end{array}$ & $\begin{array}{l}\text { Community } \\
\text { Builder }\end{array}$ & Advocacy Actor & $\begin{array}{l}\text { Creator and } \\
\text { Innovator }\end{array}$ & Preservation Player \\
\hline $\begin{array}{l}\text { Example } \\
\text { Activities }\end{array}$ & $\begin{array}{l}\text { Education, } \\
\text { health care, } \\
\text { counseling }\end{array}$ & $\begin{array}{l}\text { Social capital } \\
\text { building, public } \\
\text { education }\end{array}$ & $\begin{array}{l}\text { Advocacy and } \\
\text { lobbying }\end{array}$ & $\begin{array}{l}\text { Research or } \\
\text { artistic } \\
\text { activities }\end{array}$ & $\begin{array}{l}\text { Historical or } \\
\text { ecological } \\
\text { conservation }\end{array}$ \\
\hline $\begin{array}{l}\text { Definition of } \\
\text { Need }\end{array}$ & $\begin{array}{c}\text { Individual } \\
\text { condition }\end{array}$ & Community & Institutional & $\begin{array}{c}\text { Lack of } \\
\text { Innovation }\end{array}$ & Potential for loss \\
\hline Focus & $\begin{array}{l}\text { Service } \\
\text { recipient }\end{array}$ & $\begin{array}{l}\text { Group or } \\
\text { community }\end{array}$ & $\begin{array}{c}\text { Political or } \\
\text { economic entity }\end{array}$ & $\begin{array}{l}\text { Creative } \\
\text { process }\end{array}$ & Artifact \\
\hline $\begin{array}{c}\text { Beneficiary } \\
\text { Engagement }\end{array}$ & Direct & $\begin{array}{l}\text { Direct and } \\
\text { indirect }\end{array}$ & Indirect & Indirect & Indirect \\
\hline Output & $\begin{array}{l}\text { Amount and } \\
\text { quality of } \\
\text { service }\end{array}$ & Number engaged & $\begin{array}{l}\text { Number of issues } \\
\text { addressed }\end{array}$ & $\begin{array}{l}\text { Number of } \\
\text { elements } \\
\text { created }\end{array}$ & $\begin{array}{c}\text { Number of } \\
\text { elements preserved }\end{array}$ \\
\hline $\begin{array}{l}\text { Example } \\
\text { Outcomes }\end{array}$ & $\begin{array}{l}\text { Improved } \\
\text { beneficiary }\end{array}$ & $\begin{array}{c}\text { Social capital and } \\
\text { norms }\end{array}$ & $\begin{array}{l}\text { Influence } \\
\text { structures }\end{array}$ & $\begin{array}{l}\text { Innovative } \\
\text { artifacts }\end{array}$ & Heritage \\
\hline $\begin{array}{l}\text { Social Value } \\
\text { Proposition }\end{array}$ & $\begin{array}{c}\text { Healthy, } \\
\text { knowledgeable } \\
\text { individuals }\end{array}$ & $\begin{array}{l}\text { Healthy, stable } \\
\text { relationships and } \\
\text { communities }\end{array}$ & $\begin{array}{l}\text { Functioning and } \\
\text { just political and } \\
\text { economic systems }\end{array}$ & $\begin{array}{l}\text { Informed and } \\
\text { beautiful } \\
\text { society }\end{array}$ & $\begin{array}{l}\text { Historical and } \\
\text { ecological } \\
\text { appreciation and } \\
\text { value }\end{array}$ \\
\hline
\end{tabular}

These program activities can operate concurrently in the same organization. It is not uncommon that organizations carry out services and community building or advocacy type activities [24]. This is a potentially intriguing research question to explore how portfolios of program strategies are integrated in organizational systems. For instance, Mitchell [25] clustered service delivery portfolios of NGOs that reflected the approaches used to accomplishing organizational missions. These included: direct service delivery, grassroots mobilization, capacity building, public education, advocacy, and research. There is, however, no universal classification of delivery modalities framed as a strategic choice of managers. Mitchell's [25] work is of particular salience because it suggests the ability to organize the program 
delivery activities according to levels addressed. From the individual level of service delivery through community level grassroots organizing to social level activities associated with public education and advocacy [26]. What is missing from many classification systems is a recognition of nonprofits are also active in preservation and creative initiatives which are distinct from other forms of nonprofit program delivery methods [10]. Table 1 summarizes each activity area and details how they differ across a number of dimensions. These dimensions are drawn from systems program planning and include how need is defined, the focus of activities, level of beneficiary engagement, typical outputs, and intended outcomes $[27,28]$.

\section{Program Content Dimensions}

The features in column one differentiate each approach. These dimensions inform the logic of action inherent in each approach $[29,30]$. That logic is grounded in distinct formulations of the social value proposition [31]. The social value proposition serves as the normative justification for action [12,32]. A primary step that informs program design is the assumption of need [4,7]. Need is conceptualized as an undesirable condition that requires remediation. Organizations with varying levels of specificity define and describe the nature and character of the problem. The worldview or philosophical perspective of the actor influences how social issues are defined and interpreted [33]. This interpretation guides organizational activities [29]. How the problem is framed and how the organization defines its purpose then become a justification for program activities. The definition of the social concern facilitates articulation of the solution and furthers the nonprofit's objectives.

Each program activity is based on a different interpretation of need. In reference to services, individual deficits tend to reflect prominently in how the need is conceptualized. There is a gap or need within an individual or perhaps family unit that merits intervention and support. Conversely, the other program activities shift the level of analysis from the individual to the community or socio/political level. If an organization utilizes a community builder approach the need often reflects a concern related to social patterns, power, or cultural norms [34]. If an organization utilizes an advocacy approach the need is conceptualized as a deficiency in institutional systems [35]. This includes political, legal, or economic systems. If the organization is implementing a creative approach, the need is conceptualized as a lack of innovation or the necessity to foster creative actions that do not currently exist [36]. If the approach is preservation, then the need is conceptualized as the potential for loss. Whether that is an environmental, cultural, or historical loss the concern reflects artifacts (broadly conceived) that should be preserved.

Related to need is the focus of activity. Focus of activity is defined as what is enacted upon to achieve change. Drucker [37] and others [38] identify the focus of human service activities as the person that needs services (e.g., child in classroom). This relatively self-evident conclusion (service activities tend to be enacted on or with those they are designed to help) becomes more instrumental in defining the focus for other methods. For advocacy initiatives, the focus is the institutional entity (e.g., legislative body) that controls policy making. This distinction is prevalent in how organizations define the beneficiary of intended activities.

For nonprofits engaged in providing services, the direct beneficiary of those activities forms a coherent and logical cluster of stakeholders. It is through the delivery of services to the beneficiary that the nonprofit creates social value. The condition of these individuals' changes as a result of engagement and organizational objectives are tied to that outcome [39]. In an education context, for example, it is the students and their learning that constitutes beneficiaries. In direct engagement beneficiaries gain advantages through the output production of the provider. As services are provided the focus and beneficiary are synonymous and consequently beneficiaries should, in principle, gain increased benefit through increased engagement [40].

Moving from direct engagement of the beneficiary as focus to indirect interventions that seek to change social structures or community dynamics requires a shift in conceptualization regarding the nature of interactions. Rather than social value creation through the direct engagement of beneficiary, 
public benefit outcomes are achieved indirectly either through shifts in social structures (advocacy type activities) or shifts in culture or social capital features (community building activities) [41,42]. This is an indirect method to achieve social benefit objectives and moves the beneficiary from a direct actor in program service activities to an indirect beneficiary of program activities. Indirect activities produce benefits through the outcome of organizational activities. The volume of program outputs is less consequential to beneficiaries in this approach as benefits are only accrued when systems shift or alter.

The first three approaches function through a continuum of direct engagement with beneficiaries as the focus of activities (services) to indirect engagement political advocacy that engages policy actors to shift practices. The intermediary method of community building engages beneficiaries, but objectives are tied to group or community outcomes (safer neighborhoods). Community building is indirect in the sense that, by working through individuals, the social and community context changes. This continuum recognizes that program activities can operate on multiple levels simultaneously. For instance, organizations may provide educational programs (services), foster social cohesion (community building), and petition municipalities (advocacy actors) to address neighborhood issues.

The last two approaches seek to achieve outcomes that are distinct from those just discussed. First in relation to the creator/innovator method, the outcome for this method is the creative artifact. Need is defined as the lack of innovative artifacts or approaches [43]. This strategy is about the creation of something new and includes the range of creative outputs such as artistic, cultural, intellectual, and social. Beneficiaries in this case are those that gain advantage from the creative product. Society benefits indirectly from innovative initiatives. Not every innovation results in social value benefits, but the approach is justified by the belief that fundamentally new and creative insights add value to society. Conceptualizing the creator as a potential beneficiary is understandable, but the approach is less about the creator and more about the created artifact. If the problem definition is conceptualized as a deficit (or need) of the creator then a series of program services are enacted to enrich and benefit the potential creator. If, however, the problem is conceptualized as a lack of creative artifacts and approaches, then capable actors are a prerequisite and organizational efforts are targeted toward fostering creative production. Consequently, the focus of activity in this approach is the creative process. Outputs are related to the number of works created. Outcomes are related to how those artifacts improve the human and social condition.

In reference to preservation activities the outcome is related to safeguarding of artifacts. That can take a variety of forms, but the objective is continuity of valuable elements. This includes any variety of elements that include historical, cultural, and environment features that are determined to be at risk or in need of preservation. The need is defined as potential for loss and nonprofits become a vehicle to foster continuity. The rationale for preservation is related to the belief that conservation of resources, historical heritage, or appreciation of lost elements is important for societies. There are countless methods to achieve and support preservation initiatives and consequently the focus of activity is the preservation process. Outputs are the number and variety of elements preserved. Beneficiaries gain advantage through the existence of preserved elements. The social value justification is a belief that preserving artifacts enriches the social condition.

\section{Conclusions and Implications}

Nonprofits often seek multiple and complimentary public benefit outcomes. Nonprofits provide direct services, engage in community development, advocate for issues, and foster preservation initiatives. Blending and combining approaches to achieve objectives [25]. They create objectives that relate to multiple and concurrent outcomes that cut across the spectrum of approaches. The classification of program activities provides modest clarity to the range of programs utilized by nonprofits to create social value and highlights the distinctions among each approach. This clarity is important because it articulates and explains how the approaches are unique and require distinctive competencies. This supports research to explain how nonprofits create social value [13]. Furthermore, 
the classification across outcomes reiterates the portfolio of program options nonprofits, funders, and policy makers might consider. While approaches might operate in concert, there is substantive conceptual and operational value to distinguish how and when different approaches are utilized and how organizational resources are invested [44]. While these program options are recognized and appreciated by managers, there is relatively little in the way of conceptual models that elaborate and compare approaches.

There are a series of research questions that can follow from such a classification system. This includes questions about organizational characteristics and capabilities that support implementation and performance [45]. For instance, what organizational capabilities are required in relation to each approach? Do organizational capabilities support multiple approaches or are capabilities tied to strategies utilized? There are a number of issues related to how organizations select approaches and the composition of approaches utilized. For instance, are there common portfolios of program service activities used concurrently? There are also questions that explore the relationship between organizational objectives and program service activities utilized. Are there commonalities in how organizational objectives are articulated and the methods utilized [8]? Do organizations with similar approaches utilize a common justification for action? There are also questions in relation to how environmental characteristics influence approaches utilized [46]. For instance, how do other providers operating in a common industry affect organizational strategies? There are also questions about performance and how organizations might be more or less successful to achieve outcomes and produce social value. For instance, what are the performance outcomes and how might these be associated with program portfolios?

It is also necessary to explore and test the proposed classification system. Are there additional classification systems that can provide further specification of methods utilized by nonprofits? Given the large number of service strategies utilized, it would be useful to further classify within types. This includes classification of outcomes [10] and approaches and how organizations use these strategies to achieve program service objectives.

Conflicts of Interest: The authors declare no conflict of interest.

\section{References}

1. Brown, W.A. Strategic Management in Nonprofit Organizations; Jones \& Bartlett Learning: Burlington, MA, USA, 2014; ISBN-10: 1449618944.

2. Phills, J.A. Integrating Mission and Strategy for Nonprofit Organizations; Oxford University Press: New York, NY, USA, 2005; ISBN-10: 0195171284.

3. Stone, M.M.; Bigelow, B.; Crittenden, W. Research on strategic management in nonprofit organizations. Adm. Soc. 1999, 31, 378-423. [CrossRef]

4. Netting, F.E.; O'Connor, M.K.; Fauri, D.P. Comparative Approaches to Program Planning; John Wiley \& Sons: Hoboken, NJ, USA, 2008; ISBN-13: 978-0470126417.

5. Plantz, M.C.; Greenway, M.T.; Hendricks, M. Outcome measurement: Showing results in the nonprofit sector. New Dir. Eval. 1997, 1997, 15-30. [CrossRef]

6. Hitt, M.A.; Ireland, R.D. Hoskisson, R.E. Strategic Management Competitiveness and Globalization, 9th ed.; South-Western Cengage: Mason, OH, USA, 2011; ISBN-13: 978-1285425177; ISBN: -13.

7. Altschuld, J.W.; Kumar, D.D. Needs Assessment: An Overview; Sage: Los Angeles, CA, USA, 2010; ISBN-13: 978-1412975841.

8. Fahey, L.; Christensen, H.K. Evaluating the research on strategy content. J. Manag. 1986, 12, $167-183$. [CrossRef]

9. Herbert, T.T.; Deresky, H. Generic strategies: An empirical investigation of typology validity and strategy content. Strateg. Manag. J. 1987, 8, 135-147. [CrossRef]

10. The Urban Institute. The Nonprofit Taxonomy of Outcomes: Creating a Common Language for the Sector; Urban Institute: Washington, DC, USA, 2006. 
11. Rossi, P.H.; Lipsey, M.W.; Freeman, H.E. Evaluation: A Systmatic Approach, 7th ed.; Sage: Thousand Oaks, CA, USA, 2004; ISBN-13: 978-0761908944.

12. Moore, M.H. Managing for value: Organizational strategy in for-profit, nonprofit, and governmental organizations. Nonprofit Volunt. Sect. Q. 2000, 29, 183-208. [CrossRef]

13. Priem, R.L.; Butler, J.E.; Li, S. toward reimagining strategy research: Retrospection and prospection on the 2011 AMR decade award article. Acad. Manag. Rev. 2013, 38, 471-489. [CrossRef]

14. Anheier, H.K. Nonprofit Organizations: Theory, Management, Policy; Routledge: New York, NY, USA, 2015; ISBN-13: 978-0415550475.

15. Boris, E. Nonprofit organizations in a democracy-roles and responsibilities. In Nonprofit and Government: Collaboration and Conflict; Boris, E., Steuerle, C.E., Eds.; Urban Institute: Washington, DC, USA, 2006; pp. 1-35, ISBN-13: 978-0877667322.

16. Bushouse, B.K. Governance structures: Using IAD to understand variation in service delivery for club goods with information asymmetry. Policy Stud. J. 2011, 39, 105-119. [CrossRef]

17. Hansmann, H. The role of the nonprofit enterprise. Yale Law J. 1980, 89, 835-901. [CrossRef]

18. Moulton, S.; Eckerd, A. Preserving the publicness of the nonprofit sector. Nonprofit Volunt. Sect. Q. 2012, 41, 656-685. [CrossRef]

19. Sheehan, R.M. Mission Impact: Breakthrough Strategies for Nonprofits; John Wiley \& Sons: Hoboken, NJ, USA, 2010; ISBN-13: 978-0470449806.

20. Checkland, P. Soft systems methodology: A thirty year retrospective. Syst. Res. Behav. Sci. 2000, 17, 11-58. [CrossRef]

21. Marradi, A. Classification, typology, taxonomy. Qual. Quant. 1990, 24, 129-157. [CrossRef]

22. Kluger, M.P. The program evaluation grid. Adm. Soc. Work 2006, 30, 33-44. [CrossRef]

23. Barney, J.B.; Ketchen, D.J.; Wright, M. The future of resource-based theory: Revitalization or decline? J. Manag. 2011, 37, 1299-1315. [CrossRef]

24. Fyall, R.; Allard, S.W. Nonprofits and political activity: A joint consideration of the political activities, programs, and organizational characteristics of social service nonprofits. Hum. Serv. Organ. Manag. Leadersh. Gov. 2016, 1-26. [CrossRef]

25. Mitchell, G.E. The strategic orientations of US-based NGOs. Volunt. Int. J. Volunt. Nonprofit Organ. 2015, 26, 1874-1893. [CrossRef]

26. Lu, J. Organizational or social benefits? The progressiveness of policy advocacy in nonprofit human service organizations. Hum. Serv. Organ. Manag. Leadersh. Gov. 2015, 39, 509-521. [CrossRef]

27. Checkland, P. Systems Thinking, Systems Practice: Includes a 30-Year Retrospective, 1st ed.; Wiley: San Francisco, CA, USA, 1999; ISBN-13: 978-0471986065.

28. Julian, D.A. The utilization of the logic model as a system level planning and evaluation device. Eval. Progr. Plan. 1997, 20, 251-257. [CrossRef]

29. Garrow, E.E.; Hasenfeld, Y. Institutional logics, moral frames, and advocacy: Explaining the purpose of advocacy among nonprofit human-service organizations. Nonprofit Volunt. Sect. Q. 2014, 43, 80-98. [CrossRef]

30. Thornton, P.H.; Ocasio, W. Institutional logics. In Sage Handbook of Organizational Institutionalism; Greenwood, R., Oliver, C., Sahlin, K., Suddaby, R., Eds.; Sage: Thousand Oaks, CA, USA, 2008; pp. 99-129, ISBN-13: 978-1446270493.

31. Mendel, S.C.; Brudney, J.L. Doing good, public good, and public value. Nonprofit Manag. Leadersh. 2014, 25, 23-40. [CrossRef]

32. Mulgan, G. Measuring social value. In Stanford Social Innovation Review; Stanford Center on Philanthropy and Civil Society: Palo Alto, CA, USA, 2010.

33. Checkland, P.; Poulter, J. Soft systems methodology. In Systems Approaches to Managing Change: A Practical Guide; Reynolds, M., Holwell, S., Eds.; Springer: London, UK, 2010; ISBN-13: 978-1848828087.

34. Anheier, H.K.; Kendall, J. Interpersonal trust and voluntary associations: Examining three approaches. Br. J. Sociol. 2002, 53, 343-362. [CrossRef] [PubMed]

35. Nicholson-Crotty, J. The stages and strategies of advocacy among nonprofit reproductive health providers. Nonprofit Volunt. Sect. Q. 2009, 38, 1044-1053. [CrossRef] 
36. McCambridge, R. Grants to advance a field: 6 ludwig cancer centers get unrestricted vote of confidence and \$540 million. NPQ January, 2014. Available online: http://nonprofitquarterly.org/policysocial-context/ 23506-grants-to-advance-a-field-6-ludwig-cancer-centers-get-unrestricted-vote-of-confidence-and-540million.html (accessed on 17 May 2017).

37. Drucker, P.F. Managing the Nonprofit Organization; Harper Collins: New York, NY, USA, 1990.

38. Hasenfeld, Y. Human Service Organizations; Prentice Hall: Englewood Cliffs, NJ, USA, 1983.

39. Lovelock, C.; Wright, L. Principles of Service Marketing and Management; Prentice Hall: Englewood Cliffs, NJ, USA, 2002; ISBN-13: 978-0130404671.

40. Department for International Development. Proposed Approach for Identifying Beneficiaries for DFID's Civil Society Challenge Fund; Department for International Development, United Kingdom AID: London, UK, 2012. Available online: http:/ / www.dfid.gov.uk/Documents/funding/cscf/background-beneficiary-approach. doc (accessed on 17 May 2017).

41. Pilisuk, M.; McAllister, J.; Rothman, J. Coming together for action: The challenge of contemporary grassroots community organizing. J. Soc. Issues 1996, 52, 15-37. [CrossRef]

42. Speer, P.W.; Hughey, J. Community organizing: An ecological route to empowerment and power. Am. J. Community Psychol. 1995, 23, 729. [CrossRef] [PubMed]

43. Kramer, R.M. Voluntary agencies in the Welfare State: An analysis of the vanguard role. J. Soc. Policy 1979, 8 , 473-488. [CrossRef]

44. Kownatzki, M.; Walter, J.; Floyd, S.W.; Lechner, C. Corporate control and the speed of strategic business unit decision making. Acad. Manag. J. 2013, 56, 1295-1324. [CrossRef]

45. Hager, M.A.; Brudney, J.L. In search of strategy. Nonprofit Manag. Leadersh. 2015, 25, 235-254. [CrossRef]

46. Keats, B.W.; Hitt, M.A. A causal model of linkages among environmental dimensions, macro organizational characteristics, and performance. Acad. Manag. J. 1988, 31, 570-598. [CrossRef]

(c) 2017 by the author. Licensee MDPI, Basel, Switzerland. This article is an open access article distributed under the terms and conditions of the Creative Commons Attribution (CC BY) license (http://creativecommons.org/licenses/by/4.0/). 